\title{
Sphingosine kinase 1 promotes the metastasis of colorectal cancer by inducing the epithelial-mesenchymal transition mediated by the FAK/AKT/MMPs axis
}

\author{
SHI-QUAN LIU*, CHUN-YAN XU*, WEN-HONG WU, ZHEN-HUA FU, \\ SI-WEI HE, MENG-BIN QIN and JIE-AN HUANG \\ Department of Gastroenterology, The Second Affiliated Hospital of Guangxi Medical University, \\ Nanning, Guangxi 530007, P.R. China
}

Received May 18, 2018; Accepted October 1, 2018

DOI: 10.3892/ijo.2018.4607

\begin{abstract}
It was demonstrated that Sphingosine kinase 1 (SphK1) promotes tumor progression and confers the malignancy phenotype of colorectal cancer by activating the focal adhesion kinase (FAK) pathway. However, further clarification is required to determine if SphK1 promotes the metastasis of colorectal cancer by inducing epithelial-mesenchymal transition (EMT), and its mechanisms have not been fully elucidated. Immunohistochemistry staining was used to detect protein expression in normal colonic mucosa tissues and colorectal cancer tissues. Cells were transfected to overexpress SphK1, downregulate SphK1 or downregulate FAK. An MTT assay was used to detect the drug toxicity to cells. Transwell and wound healing assays were used to detect cell migration ability. Reverse transcription-polymerase chain reaction and western blot analysis were used to detect the expression of mRNA and protein, respectively. Scanning electron microscopy was used to observe the microvilli and pseudopodia of the cells. The analysis of protein expression in 114 human colorectal cancer tissues demonstrated that the expressions of SphK1, FAK, phosphorylated (p)-FAK, E-cadherin and vimentin were associated with the metastasis of colorectal cancer. Furthermore, the patients with colorectal cancer with SphK1-positive cancer demonstrated poorer prognosis compared with SphK1-negative cancer. FAK knockdown and SphK1 knockdown of human colon cancer
\end{abstract}

Correspondence to: Professor Shi-Quan Liu or Professor Jie-An Huang, Department of Gastroenterology, The Second Affiliated Hospital of Guangxi Medical University, 166 Daxuedong Road, Nanning, Guangxi 530007, P.R. China

E-mail:poempower@163.com

E-mail: hjagxmu@163.com

${ }^{*}$ Contributed equally

Key words: Sphingosine kinase 1, metastasis, epithelial-mesenchymal transition, biomarker, colorectal cancer
RKO cells inhibited the EMT and migrational potency, along with the expression of p-FAK, p-protein kinase B (AKT) and matrix metalloproteinase (MMP)2/9. In contrast, SphK1 overexpression promoted EMT, migrational potency, and the expression of p-FAK, p-AKT and MMP2/9 in HT29 cells. Additionally, the EMT and migrational potency of SphK1-overexpressing HT29 cells was suppressed by a FAK inhibitor, and the expression of p-FAK, p-AKT and MMP2/9 was suppressed by blocking the FAK pathway. In conclusion, SphK1 promoted the migration and metastasis of colon cancer by inducing EMT mediated by the FAK/AKT/MMPs axis.

\section{Introduction}

Poor prognosis and a lack of effective therapeutic strategies pose prinicipal challenges for the treatment of colorectal cancer (1). There is an urgent requirement to identify a better therapeutic target in the treatment of colorectal cancer.

Sphingosine kinase 1 (SphK1) is involved in the regulation of cellular behaviors. Accumulating evidence suggested that the activation of SphK1 contributes to tumor growth, neovascularization, metastasis and drug resistance (2). SphK1 is overexpressed in multiple types of human cancer tissues, including colorectal cancer tissues (3). Furthermore, migrational potency of cancer cell was improved by the overexpression of SphK1 and decreased by the knockdown of SphK1 (4). Our previous study demonstrated that the expression of SphK1 in primary colorectal cancer tissues was significantly increased compared with matched normal tissues (5). A further previous study suggested that the migrational potency of colon cancer LOVO cells was enhanced by the overexpression of SphK1, and inhibited by suppression of SphK1 via short hairpin (sh)RNA transfection (6). These results suggested that SphK1 may serve an important role in promoting the migration and metastasis of colorectal cancer. However, the precise molecular mechanism still requires investigation.

Emerging evidence suggested an association between the development of metastasis and epithelial-mesenchymal transition (EMT) processes in cancer (7). EMT is defined as the process of epithelial cell transformations towards 
the mesenchymal phenotype that results in metastasis (8) Accordingly, epithelial tumor cells were associated with the reactivation of EMT (9). EMT was characterized by a downregulation of epithelial markers, including E-cadherin (10), an upregulation of mesenchymal markers, including vimentin (11) and fibronectin (12), and the production of matrix-degrading enzymes, including matrix metalloproteinase (MMP)2 and MMP9 $(13,14)$. The migrational potency of cells was facilitated once the EMT process was reactivated in epithelial tumor cells, including colon cancer cells (15). Previous studies demonstrated that focal adhesion kinase (FAK), phosphoinositide 3 kinase $(\mathrm{PI} 3 \mathrm{~K})$ /protein kinase $\mathrm{B}$ (AKT) and MMP2/9 were involved in mediating the EMT process (16-19); however, the regulatory mechanism has not yet been fully understood.

It was confirmed that SphK1 promoted tumor progression and advanced malignancy phenotype of colon cancer by regulating the FAK pathway and upregulating the production of MMP2/9 (4). Recent studies suggested that the FAK pathway was one of the most important factors in regulating EMT $(20,21)$. Furthermore, tyrosine phosphorylation of $\mathrm{p} 85$ subunits of PI3K was modulated by FAK (22), whereas, PI3K/AKT affected MMP2/9 secretion in cancer cells (23). Therefore, in the present study, the hypothesis that SphK1 promotes the migration and metastasis of colorectal cancer by EMT induction mediated by the FAK/AKT/MMPs axis was investigated.

\section{Materials and methods}

Tissue specimens. Tissues samples from patients were collected at the First Affiliated Hospital of Guangxi Medical University (Guangxi, China) from March 2013 to October 2013 (24). There were 71 male and 43 female patients included in the present study, all of whom were newly diagnosed and had not received any chemotherapy or radiotherapy previously, and the age of the patients ranged between 25 and $83(56.58 \pm 13.47)$ years old (24). Based on the National Comprehensive Cancer Network classification, 19 patients were diagnosed with stage I CRC, 44 with stage II CRC, 30 with stage III CRC and 21 with stage IV CRC (24). The study was approved by the Institutional Ethics Committee of Guangxi Medical University under full consideration of the Helsinki declaration of human rights. Written informed consent was obtained from all patients.

Immunohistochemistry staining. Immunohistochemistry staining was performed on deparaffinized $4-\mu \mathrm{m}$ thick sections according to the manufacturer's protocol. Endogenous peroxidase activity was blocked with $3 \%$ hydrogen peroxide at room temperature for $10 \mathrm{~min}$. Subsequently, the sections were blocked with $10 \%$ normal goat serum (Beyotime Institute of Biotechnology, Haimen, China) in PBS for $1 \mathrm{~h}$, incubated with primary antibody for overnight $4^{\circ} \mathrm{C}$, and finally incubated with undiluted horseradish peroxidase-conjugated secondary antibody for $30 \mathrm{~min}$ at $37^{\circ} \mathrm{C}$. The secondary antibody was the $\mathrm{B}$ reagent in an immunohistochemistry kit (Zhongshan Golden Bridge Biotechnology, Beijing, China; cat. no. PV-9000). Visualization of the immunohistochemical reaction was performed using DAB as the chromogen. The slides were evaluated by two pathologists independently. Protein expression was examined by using five random fields on each slide at using a light microscope (magnification, x100; PH50-3A43L-PL optical microscope; Phmias2008 Computer Image Analysis System; Phoenix Optical Co., Ltd., Jiangxi, China). Polyclonal antibodies against SphK1 (cat. no. 10670-1-AP; 1:400) and FAK (cat. no. 12636-1-AP; 1:800) were from ProteinTech Group, Inc. (Chicago, IL, USA). Polyclonal antibodies against phosphorylated (p)-FAK (Tyr397; cat. no. 8556P; 1:1,200) were from Abcam (Cambridge, UK). Polyclonal antibodies against E-cadherin (cat. no. bs-1519R; 1:200) and vimentin (cat. no. bs-8533R; 1:200) were from BIOSS (Beijing, China). The degree of staining was determined by semi-quantitative evaluation and categorized by the extent and intensity of staining as follows: i) The percentage of positively stained cells $<5 \%$ was scored as $0,5-25 \%$ scored as $1,26-50 \%$ scored as $2,>50 \%$ scored as 3 ; and ii) The intensity of staining was scored as: 0 , achromatic; 1, light yellow; 2, yellow; and 3 , brown. The two scores were added for the final score: $0-2$, negative $(-)$ and $\geq 3$, positive $(+)$.

Cell culture and transfection. The human adenocarcinoma cell line RKO and HT29 (American Type Culture Collection, Manassas, VA, USA) were cultured in Dulbecco's modified Eagle's medium (Gibco; Thermo Fisher Scientific, Waltham, MA, USA) supplemented with $10 \%$ fetal bovine serum (ExCell Biology, Inc., Shanghai, China) and penicillin/streptomycin $(100 \mathrm{U} / \mathrm{ml})$ at $37^{\circ} \mathrm{C}$ with $5 \% \mathrm{CO}_{2}$. The Lenti-FAK-EGFP-miR $\left(5 \times 10^{7} \mathrm{TU} / \mathrm{ml}\right)$ and Lenti-SPHK1-EGFP-miR $\left(5 \times 10^{7} \mathrm{TU} / \mathrm{ml}\right)$ (Shanghai R\&S Biotechnology Co., Ltd., Shanghai, China) were introduced into RKO cells respectively via lentiviral transfection [multiplicity of infection (MOI) =30]. RKO cells were additionally transfected with the blank vector

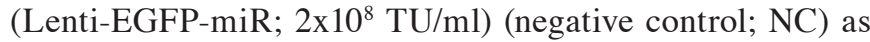
control (MOI=30). Lentiviral vector encoding human SphK1 (Lenti-SPHK1-IRES-EGFP; 9x10 $7 \mathrm{TU} / \mathrm{ml}$ ) was introduced into HT29 cells via lentiviral transfection (MOI=20). HT29 cells were additionally transfected with the blank vector (Lenti-EGFP; $10^{9} \mathrm{TU} / \mathrm{ml}$ ) [negative control (NC); MOI=20]. The POLOdeliverer ${ }^{\mathrm{TM}} 3000$ Transfection Reagent was purchased from Shanghai R\&S Biotechnology Co., Ltd. Stably transfected cells were selected for subsequent experiments. The time interval between transfection and subsequent experimentation was 14 days.

Reverse transcription (RT)-quantitative (q)PCR analysis. RNA isolation was performed using the Total RNA Extraction kit (Tiangen Biotech Co., Ltd., Beijing, China), according to the manufacturer's protocol. cDNA synthesis was performed using the RT kit (Takara Bio, Inc., Otsu, Japan). RT was performed using 2.0 $\mu \mathrm{l} 5 \mathrm{X}$ gDNA Eraser Buffer, $1.0 \mu \mathrm{l}$ gDNA Eraser, $1 \mu \mathrm{g}$ Total RNA and RNase Free $\mathrm{dH}_{2} \mathrm{O}$ to a total volume of $10 \mu \mathrm{l}$. The reaction conditions were $42^{\circ} \mathrm{C}$ for $2 \mathrm{~min}$ and rapidly cooled to $4^{\circ} \mathrm{C}$. Subsequently, $10.0 \mu \mathrm{l}$ reaction solution, $1.0 \mu \mathrm{l}$ PrimeScript RT Enzyme Mix 1, $1.0 \mu \mathrm{l}$ RT Primer Mix, $4.0 \mu 1$ 5X PrimeScript Buffer 2 and $4.0 \mu 1$ RNase Free $\mathrm{dH}_{2} \mathrm{O}$ were used. The reaction conditions were $37^{\circ} \mathrm{C}$ for $15 \mathrm{~min}, 85^{\circ} \mathrm{C}$ for $5 \mathrm{sec}$, rapidly cooled to $4^{\circ} \mathrm{C}$ and stored at $-20^{\circ} \mathrm{C}$. A fluorescence-based qPCR method was performed using $2 \mu \mathrm{l}$ cDNA, $10 \mu \mathrm{l}$ SYBR Green (Takara Bio, Inc.), $0.6 \mu 1$ PCR forward primer $(10 \mu \mathrm{M}), 0.6 \mu 1 \mathrm{PCR}$ reverse primer

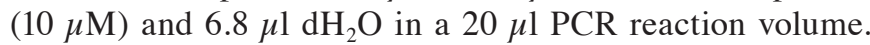


The RT-qPCR reaction was run on a StepOne Real-Time PCR system (Applied Biosystems; Thermo Fisher Scientific, Inc.). The cycling parameters were as follows: Denaturing at $95^{\circ} \mathrm{C}$ for $30 \mathrm{sec}, 40$ cycles at denaturing at $95^{\circ} \mathrm{C}$ for $5 \mathrm{sec}$, primer annealing at $60^{\circ} \mathrm{C}$ for $34 \mathrm{sec}$ and extension temperature at $95^{\circ} \mathrm{C}$ for $15 \mathrm{sec}$; final extension at $60^{\circ} \mathrm{C}$ for $1 \mathrm{~min}$ and final denaturing at $95^{\circ} \mathrm{C}$ for $15 \mathrm{sec}$. Gene expression levels were determined using the $2^{-\Delta \Delta \mathrm{Cq}}$ method (25). The primers were from Takara Bio, Inc. The sequences were as follows: GAPDH, forward: 5'-GCA CCG TCA AGG CTG AGA AC-3', reverse: 5'-TGG TGA AGA CGC CAG TGGA-3'; SphK1, forward: 5'-GGC TTC ATT GCT GAT GTG GA-3', reverse: 5'-AGG AAG GTG CCC AGA GTG AA-3'; FAK, forward: 5'-CAA CCA CCT GGG CCA GTA TTA TC-3', reverse: 5'-CCA TAG CAG GCC ACA TGC TTTA-3'; vimentin, forward: 5'-TGA CAT TGA GAT TGC CAC CTA CAG-3', reverse: 5'-TCA ACC GTC TTA ATC AGA AGT GTCC-3'; E-cadherin, forward: 5'-GAG TGC CAA CTG GAC CAT TCA GTA-3', reverse: 5'-AGT CAC CCA CCT CTA AGG CCA TC-3'; MMP2, forward: 5'-GCT CCA CCA CCT ACA ACT TTG AGAA-3', reverse: 5'-TGT CAT AGG ATG TGC CCT GGAA-3'; MMP9, forward: 5'-TGG GCT GCT GCT TTG CT-3', reverse: 5'-GCC TGT CGG TGA GAT TGG TT-3'; and fibronectin, forward: 5'-GAC CAC ATC GAG CGG ATC TG-3', reverse: 5'- GTC TCT TGG CAG CTG ACT CC-3'.

Western blot analysis. Total proteins were extracted using radioimmunoprecipitation buffer (Beyotime Institute of Biotechnology). Protein concentrations were measured by a bicinchoninic acid assay (Solarbio Biotech Co., Ltd., Beijing, China) according to the manufacturer's protocol. A total of $30 \mu \mathrm{g}$ of protein from each sample was separated via $12 \%$ SDS-PAGE (Beyotime Institute of Biotechnology) for $1 \mathrm{~h}$ at $100 \mathrm{~V}$, and subsequently transferred onto nitrocellulose membranes. Samples were blocked with 5\% non-fat milk in Tris-buffered saline with Tween-20 (Solarbio Biotech Co., Ltd.) for $1 \mathrm{~h}$ at room temperature. The membranes were incubated overnight at $4^{\circ} \mathrm{C}$ with primary antibodies diluted in WB Antibody Diluent (Beyotime Institute of Biotechnology). Subsequently, the membranes and secondary antibodies were incubated for $1 \mathrm{~h}$ at room temperature. Bands were quantified by Odyssey infrared imaging (LI-COR Biosciences, Lincoln, NE, USA) and GAPDH served as the internal reference. The blots were analyzed with Quantity One 4.6.2 software (Bio-Rad Laboratories, Inc., Hercules, CA, USA). Polyclonal antibodies against E-cadherin (cat. no. 3195; 1:1,000), p-FAK (Tyr397; cat. no. 8556P; 1:1,000), AKT (cat. no. 4691; 1:1,000) and p-AKT (Ser473; cat. no. 4060; 1:1,000) were from Cell Signaling Technology, Inc., Danvers, MA, USA. Polyclonal antibodies against SphK1 (cat. no. 10670-1-AP; 1:500), FAK (cat. no. 12636-1-AP; 1:2,000), MMP2 (cat. no. 10373-2-AP; 1:500), MMP9 (cat. no. 10375-2-AP; 1:500), vimentin (cat. no. 10366-1-AP; 1:500), fibronectin (cat. no. 15613-1-AP; 1:500) and GAPDH (cat. no. 10494-1-AP; 1:1,000) were purchased from ProteinTech Group, Inc. IRDy ${ }^{\circledR}$ 680RD goat anti-rabbit (cat. no. 60329-11; 1:10,000) secondary antibodies were from LI-COR Biosciences.

Cells viability. Cells $\left(10 \times 10^{3}\right)$ were seeded into a 96-well plate. Following treatment with the FAK pathway inhibitor
(PF-562271) at concentrations of $0,2.5,5$ and $10 \mu \mathrm{M}$ for 24,48 and $72 \mathrm{~h}$, the cells were incubated in fresh medium containing MTT solution $(2 \mathrm{mg} / \mathrm{ml})$ and were incubated for $4 \mathrm{~h}$ at $37^{\circ} \mathrm{C}$ in the dark. Following removal of the MTT solution, $150 \mu \mathrm{l}$ dimethyl sulfoxide was added to dissolve the formazan crystals and the absorbance (A) at $450 \mathrm{~nm}$ was measured using a fully automated microplate reader (ELx800 ${ }^{\mathrm{TM}}$; BioTek Instruments, Inc., Winooski, VT, USA). Cell viability $(\%)=\mathrm{A} 450$ (sample)/A450 (control) x100.

Transwell and wound healing assays. The cells $\left(1 \times 10^{5}\right)$ were cultured in fresh serum-free medium in the upper chambers of Transwell plates. The lower chambers contained fresh medium with $10 \% \mathrm{FBS}$. After $48 \mathrm{~h}$ of incubation at $37^{\circ} \mathrm{C}$, cells remaining on the upper surface of the membrane were removed. The cells that migrated to the lower membrane surface were fixed with $4 \%$ paraformaldehyde (Beyotime Institute of Biotechnology) at $4^{\circ} \mathrm{C}$ for $5 \mathrm{~min}$ and stained with $0.1 \%$ crystal violet solution (Beyotime Institute of Biotechnology) at $37^{\circ} \mathrm{C}$ for $20 \mathrm{~min}$. Migrating cells were counted in five random fields under a light microscope (Nikon Corporation, Tokyo, Japan; (magnification, $\mathrm{x} 200$ ). The migrated cells were counted with Nikon microscope software (version 4.0; Nikon Corporation). Cells were seeded into a 6 -well cell culture plate. When the cells reached $80-90 \%$ confluency, the cells were scratched with a pipette tip $(1 \mathrm{~mm})$. Images were acquired after cells were cultured in medium for 0,24 and $48 \mathrm{~h}$. The migration distance was measured with the microscope software (Nikon Corporation).

Scanning electron microscope analysis. Cells were grown on cover glass slides placed in 6-well plates. Subsequent to being treated, cells were fixed with $3 \%$ glutaraldehyde at $4^{\circ} \mathrm{C}$ for $2 \mathrm{~h}$, gradient ethanol dehydration: $50 \%$ for $10 \mathrm{~min}$ one time and $70 \%$ for $10 \mathrm{~min}$ one time. Gold was used for sputter coating. Images of RKO cells and HT29 cells were obtained using the scanning electron microscope of VEGA3, TESCAN (Brno-Kohoutovice, Czech Republic) and S4800 (Hitachi, Ltd., Tokyo, Japan).

Statistical analysis. Each experiment was performed at least three times. Statistical analysis was performed using SPSS 20.0 software (IBM, Corp., Armonk, NY, USA). The significance between SphK1, FAK, p-FAK, E-cadherin, vimentin and clinicopathological characteristics of the patients was assessed with the $\chi^{2}$ test. Survival curves were compared using the log-rank test. The PCR was analyzed by the Mann-Whitney $\mathrm{U}$ test. Statistical significance was determined by unpaired Student's t-test. Analysis of variance was performed, followed by the Least Significant Difference's test for multiple comparisons. $\mathrm{P}<0.05$ was considered to indicate a statistically significant difference.

\section{Results}

Expression of SphK1, FAK, p-FAK, E-cadherin and vimentin in colorectal cancer tissues and their clinical significance. Immunohistochemistry staining demonstrated that the expression density of SphK1, FAK, p-FAK and vimentin in colorectal cancer tissues were higher compared with 

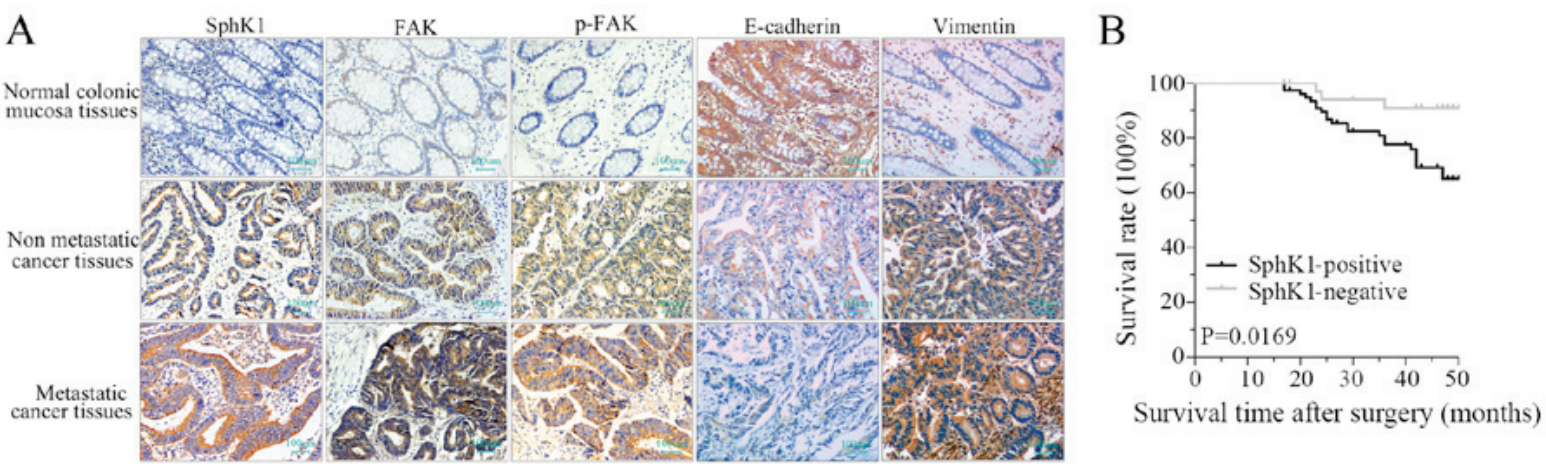

Figure 1. Expression of SphK1, FAK, p-FAK, E-cadherin and vimentin in colorectal cancer. (A) Immunohistochemical staining of SphK1, FAK, p-FAK, E-cadherin and vimentin proteins in normal colonic mucosa tissues, non-metastatic cancer tissues and metastatic cancer tissue samples (magnification, x100). (B) Survival rate of patients with SphK1-positive and SphK1-negative colorectal cancer. P=0.0169 vs. SphK1-negative. SphK1, Sphingosine kinase 1; FAK, focal adhesion kinase; $p$, phosphorylated.

Table I. Expression of SphK1, FAK and p-FAK in tissues assessed by immunohistochemistry staining.

\begin{tabular}{|c|c|c|c|c|c|c|c|c|c|c|}
\hline \multirow[b]{2}{*}{ Colonic samples } & \multirow[b]{2}{*}{$\mathrm{n}$} & \multicolumn{3}{|c|}{ SphK1 } & \multicolumn{3}{|c|}{ FAK } & \multicolumn{3}{|c|}{ p-FAK } \\
\hline & & - & + & P-value & - & + & P-value & - & + & P-value \\
\hline Normal colonic mucosa tissues & 50 & 44 & 6 & 0.001 & 40 & 10 & 0.001 & 43 & 7 & 0.001 \\
\hline Non-metastatic cancer tissues & 63 & 27 & 36 & & 29 & 34 & & 37 & 26 & \\
\hline Metastatic cancer tissues & 51 & 9 & 42 & & 6 & 45 & & 13 & 38 & \\
\hline
\end{tabular}

SphK1, Sphingosine kinase 1; FAK, focal adhesion kinase; p, phosphorylated.

Table II. Expression of E-cadherin and vimentin in tissues assessed by immunohistochemistry staining.

\begin{tabular}{|c|c|c|c|c|c|c|c|}
\hline \multirow[b]{2}{*}{ Colonic samples } & \multirow[b]{2}{*}{$\mathrm{n}$} & \multicolumn{3}{|c|}{ E-cadherin } & \multicolumn{3}{|c|}{ Vimentin } \\
\hline & & - & + & P-value & - & + & P-value \\
\hline Normal colonic mucosa tissues & 50 & 9 & 41 & 0.001 & 42 & 8 & 0.001 \\
\hline Non-metastatic cancer tissues & 63 & 15 & 48 & & 40 & 23 & \\
\hline Metastatic cancer tissues & 51 & 27 & 24 & & 19 & 32 & \\
\hline
\end{tabular}

normal colonic mucosa tissues, whereas, the expression of E-cadherin was lower compared with normal colonic mucosa tissues (Fig. 1A; Tables I and II). Furthermore, the expression of SphK1, FAK, p-FAK and vimentin in metastatic cancer tissues were higher compared with non-metastatic cancer tissues, whereas, the expression of E-cadherin was lower (Fig. 1A; Tables I and II). As presented in Tables III and IV, the positive scores of SphK1, FAK, p-FAK and vimentin expression in advanced tumors (stage III and stage IV) with lymph nodes and distant metastases of colorectal cancer tissues were higher compared with those identified in less advanced tumors (stage I and stage II) without-lymph nodes and distant metastases. However, the positive rate of E-cadherin was lower in advanced tumors. There was a significant difference in E-cadherin and vimentin expression between different infiltration depths in colorectal cancer tissues; however, there was no significant difference in SphK1, FAK and p-FAK expression. These results suggested that the expression of SphK1, FAK, p-FAK, E-cadherin and vimentin was associated with the malignant invasion and metastasis of colorectal cancer.

Association between SphK1 expression and survival of patients with colorectal cancer. Patients with colorectal cancer with SphK1-positive cancer cells had a significantly lower survival rate compared with patients with SphK1-negative cancer (Fig. 1B; $\mathrm{P}=0.0169$ ). The results suggested that the prognosis of patients with colorectal cancer with SphK1-positive tumor was poorer. Therefore, SphK1 may be used as a prognostic indicator for patients with colorectal cancer.

Suppression of FAK inhibits the cell migrational potency, EMT, and the expression of $p-A K T$ and MMPs in RKO cells. Our previous study demonstrated that the relative protein expression of $\mathrm{p}$-FAK was $0.93 \pm 0.02$ in $\mathrm{Caco} 2$ cells, $0.71 \pm 0.03$ 
Table III. Clinicopathological characteristics of the patients with colorectal cancer and SphK1, FAK and p-FAK expression in the colorectal cancer tissues.

\begin{tabular}{|c|c|c|c|c|c|c|c|c|c|c|}
\hline \multirow[b]{2}{*}{ Pathologic feature } & \multicolumn{4}{|c|}{ SphK1 } & \multicolumn{3}{|c|}{ FAK } & \multicolumn{3}{|c|}{ p-FAK } \\
\hline & $\mathrm{n}$ & - & + & P-value & - & + & P-value & - & + & P-value \\
\hline \multicolumn{11}{|l|}{ Infiltration depth } \\
\hline Mucosa and superficial muscular layer & 21 & 10 & 11 & 0.080 & 9 & 12 & 0.181 & 10 & 11 & 0.701 \\
\hline Deep muscular layer and below & 93 & 26 & 67 & & 26 & 67 & & 40 & 53 & \\
\hline \multicolumn{11}{|l|}{ TNM staging } \\
\hline I/II stage & 63 & 27 & 36 & 0.004 & 29 & 34 & 0.001 & 37 & 26 & 0.001 \\
\hline III/IV stage & 51 & 9 & 42 & & 6 & 45 & & 13 & 38 & \\
\hline \multicolumn{11}{|l|}{ Lymphatic metastasis } \\
\hline- & 68 & 27 & 41 & 0.023 & 29 & 39 & 0.001 & 37 & 31 & 0.006 \\
\hline+ & 46 & 9 & 37 & & 6 & 40 & & 13 & 33 & \\
\hline \multicolumn{11}{|l|}{ Distant metastasis } \\
\hline- & 93 & 35 & 58 & 0.003 & 34 & 59 & 0.004 & 48 & 45 & 0.001 \\
\hline+ & 21 & 1 & 20 & & 1 & 20 & & 2 & 19 & \\
\hline
\end{tabular}

SphK1, Sphingosine kinase 1; FAK, focal adhesion kinase; p, phosphorylated.

Table IV. Clinicopathological characteristics of the patients with colorectal cancer and E-cadherin, vimentin expression in the colorectal cancer tissues.

\begin{tabular}{|c|c|c|c|c|c|c|c|}
\hline \multirow[b]{2}{*}{ Pathologic feature } & \multirow[b]{2}{*}{$\mathrm{n}$} & \multicolumn{3}{|c|}{ E-cadherin } & \multicolumn{3}{|c|}{ Vimentin } \\
\hline & & - & + & P-value & - & + & P-value \\
\hline \multicolumn{8}{|l|}{ Infiltration depth } \\
\hline Mucosa and superficial muscular layer & 21 & 3 & 18 & 0.018 & 16 & 5 & 0.013 \\
\hline Deep muscular layer and below & 93 & 39 & 54 & & 43 & 50 & \\
\hline \multicolumn{8}{|l|}{ TNM staging } \\
\hline I/II stage & 63 & 15 & 48 & 0.001 & 40 & 23 & 0.005 \\
\hline III/IV stage & 51 & 27 & 24 & & 19 & 32 & \\
\hline \multicolumn{8}{|l|}{ Lymphatic metastasis } \\
\hline- & 68 & 16 & 52 & 0.001 & 41 & 27 & 0.027 \\
\hline+ & 46 & 26 & 20 & & 18 & 28 & \\
\hline \multicolumn{8}{|l|}{ Distant metastasis } \\
\hline- & 93 & 30 & 63 & 0.033 & 55 & 38 & 0.001 \\
\hline+ & 21 & 12 & 9 & & 4 & 17 & \\
\hline
\end{tabular}

TNM, tumor, node and metastasis.

in HT29 cells, $0.96 \pm 0.01$ in RKO cells and $0.80 \pm 0.02$ in HCT116 cells (26). The protein expression of p-FAK in RKO cells was the highest. Therefore, RKO cells were selected for FAK shRNA stable transfection and the FAK and p-FAK expression were successfully suppressed (Fig. 2A-C). The expression of p-AKT, MMP2/9, vimentin and fibronectin was decreased with the suppression of FAK, whereas, E-cadherin was increased, and no noticeable alteration occurred for AKT expression (Fig. 3A and B). The microvilli and pseudopodia of FAK knockdown RKO cells [FAK(-)-RKO] were decreased compared with transfection negative control (NC) and control (Con) RKO cells (Fig. 3C). These results suggested that the EMT process was inhibited by suppression of FAK by decreasing p-AKT and MMP2/9. The migrational potency of cells may be facilitated once the EMT process is reactivated in colorectal cancer cells (15). Therefore, the migrational potency of RKO cells was significantly suppressed by FAK knockdown (Fig. 4A and B; $\mathrm{P}<0.05$ ). 

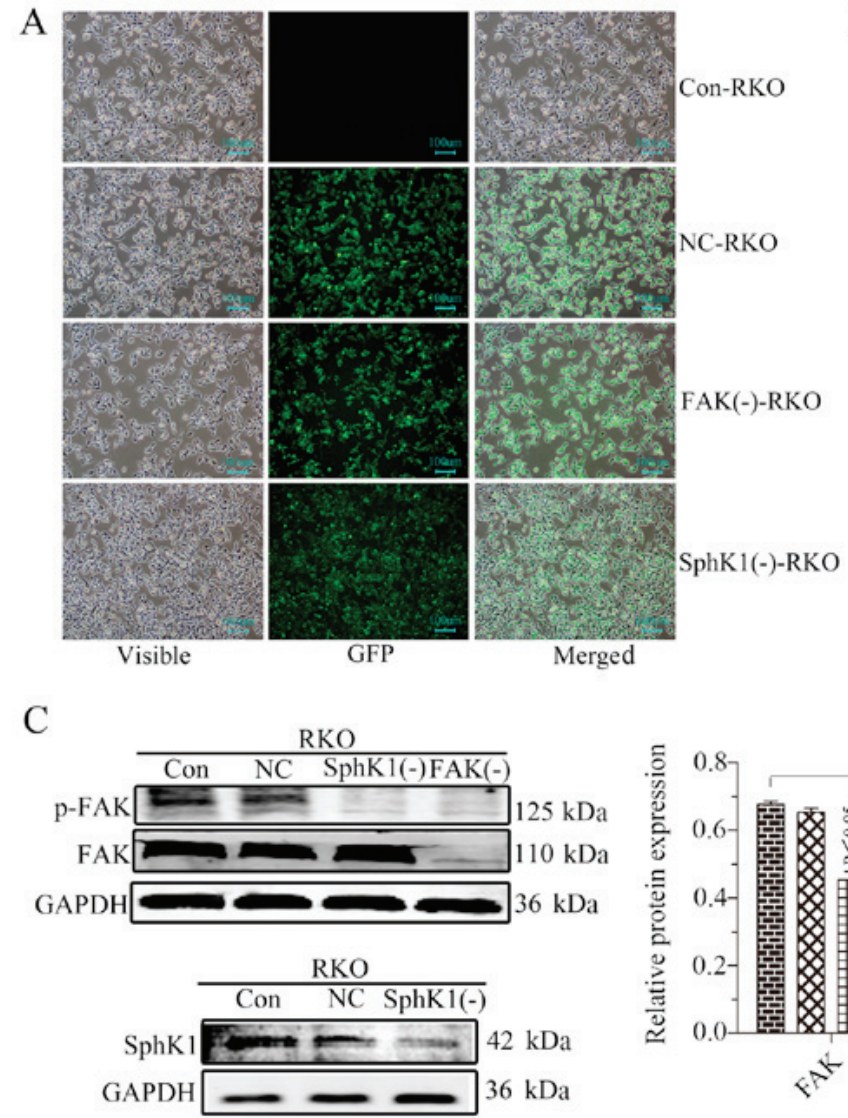

B
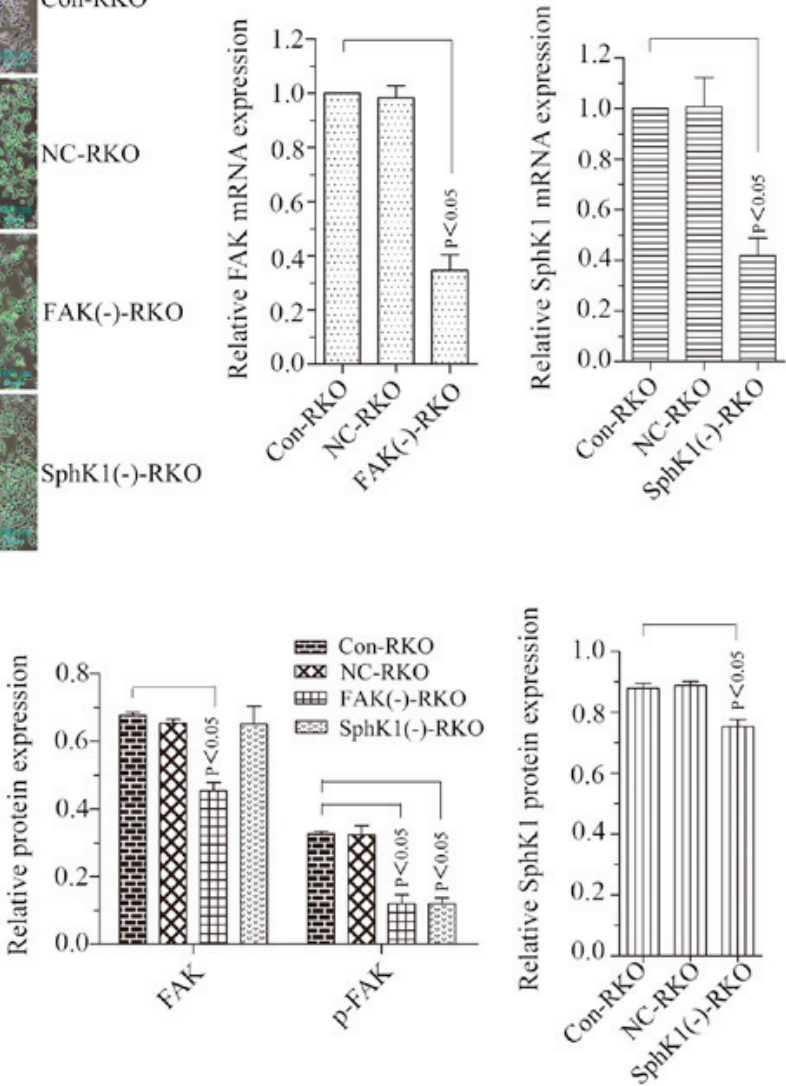

Figure 2. FAK knockdown or SphK1 knockdown downregulates FAK/p-FAK or SphK1 expression in RKO cells, respectively. (A) Transfected and untransfected RKO cells were detected using a fluorescence microscope (magnification, x100). (B) Reverse transcription-polymerase chain reaction analysis for FAK and SphK1 mRNA. GAPDH was used as a reference and the Con-RKO was set to 1. (C) Western blot analysis. GAPDH was used as an internal control. All data are presented as the mean \pm standard deviation of three independent experiments. FAK, focal adhesion kinase; SphK1, Sphingosine kinase 1; Con, control; $\mathrm{NC}$, negative control; GFP, green fluorescent protein.

SphK1 knockdown inhibits the cell migrational potency, EMT, and the expression of $p-F A K, p-A K T$ and MMPs in RKO cells. RKO cells were used for SphK1 shRNA stable transfection. SphK1 mRNA and protein expressions were successfully suppressed in the transfected RKO cells (Fig. 2A and B). The expression of p-FAK, p-AKT and MMP2/9 was decreased with the suppression of SphK1 in RKO cells. However, there were no noticeable alterations of FAK and AKT expression levels (Figs. 2C and 3A-C). SphK1 knockdown was accompanied by an increased expression of E-cadherin and a decrease in the expression of vimentin and fibronectin (Fig. 3A and B). The microvilli and pseudopodia of SphK1 knockdown RKO cells [SphK1(-)-RKO] were decreased compared with NC and Con RKO cells (Fig. 3C). These results suggested that the EMT was repressed with the suppression of SphK1 by decreasing p-FAK, p-AKT and MMP2/9. The migrational potency of cells was facilitated once the EMT process was reactivated in colorectal cancer cells (17). Therefore, the migrational potency of RKO cells was additionally significantly decreased with the knockdown of SphK1 (Fig. 4; P<0.05).

SphK1 overexpression strengthens cell migrational potency, EMT, and the expression of $p-F A K, p-A K T$ and MMPs in HT29 cells. Our previous study demonstrated that the relative protein expression of SphK1 was $0.96 \pm 0.02$ in Caco 2 cells, $0.61 \pm 0.07$ in HT29 cells, $0.92 \pm 0.05$ in RKO cells and $0.97 \pm 0.02$ in HCT116 cells (22). The protein expression of SphK1 in HT29 cells was the lowest. HT29 cells were used for stable transfection of the SphK1 overexpressing vector (Fig. 5). SphK1 mRNA and protein expression levels were significantly increased in the transfected cells (Fig. $5 \mathrm{~A}$ and $\mathrm{C} ; \mathrm{P}<0.05$ ). In contrast to the cells with knockdown of SphK1, the negatively transfected control (NC) and Con-HT29 cells, the expression levels of p-FAK, p-AKT and MMP2/9 were significantly increased in SphK1-overexpressing HT29 cells [SphK1(+)-HT29] (Fig. 5B and $\mathrm{C} ; \mathrm{P}<0.05)$. However, there were no statistical differences in FAK and AKT expression levels among SphK1(+)-HT29 cells, NC-HT29 cells and Con-HT29 cells (Fig. 5B and C; $\mathrm{P}>0.05)$. Compared with NC-HT29 and Con-HT29 cells, the expression of E-cadherin decreased, whereas, vimentin and fibronectin increased in SphK1(+)-HT29 cells (Fig. 5B and C), along with the microvilli and pseudopodia (Fig. 5D). These results suggested the EMT was induced by the overexpression of SphK1 by increasing p-FAK, p-AKT and MMP2/9. The migrational potency of cells is facilitated once the EMT process is reactivated in colorectal cancer cells (13). The migrational potency of the cells was additionally increased with the upregulation of SphK1 (Fig. 5E). 

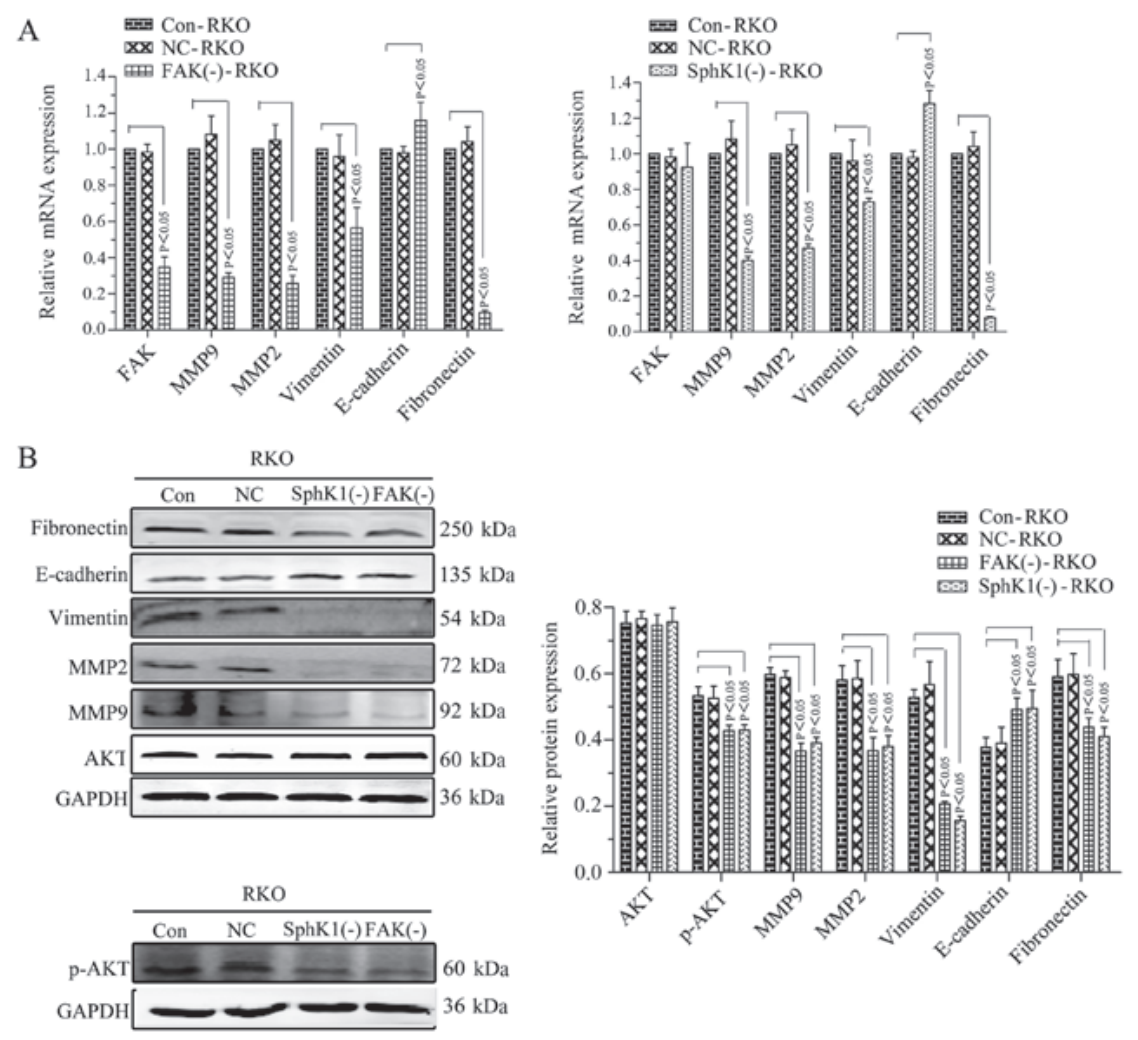

$\mathrm{C}$
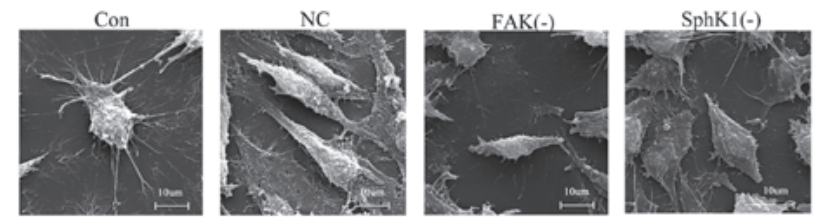

Figure 3. FAK knockdown or SphK1 knockdown inhibits the epithelial-mesenchymal transition of RKO cells mediated by the FAK/AKT/MMPs axis. (A) RT-PCR analysis for the target molecules. GAPDH was used as a reference and the Con-RKO was set to 1. (B) Western blot analysis. GAPDH was used as an internal control. (C) Microvilli and pseudopodia of Con, NC, FAK(-) and SphK1(-) RKO cells under scanning electron microscopy (magnification, x 5.00k). All data are presented as the mean \pm standard deviation of three independent experiments. FAK, focal adhesion kinase; SphK1, Sphingosine kinase 1; AKT, protein kinase B; MMP, matrix metalloproteinase; Con, control; NC, negative control; p, phosphorylated.
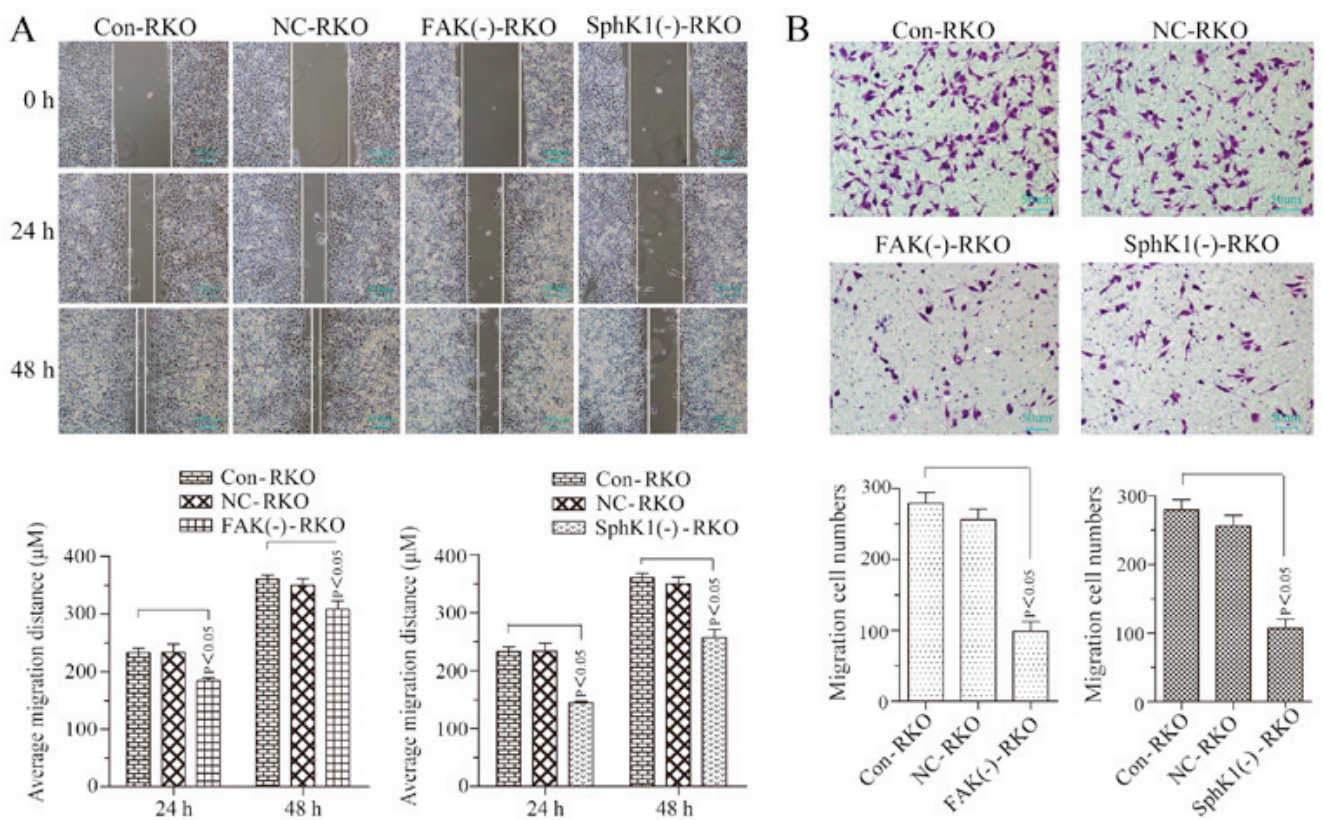

Figure 4. FAK knockdown or SphK1 knockdown decreases the migrational potency of RKO cells. (A) Cell migrational potency demonstrated by a wound healing assay (magnification, x100) and analysis. (B) Cell migrational potency demonstrated by a Transwell assay (magnification, x200) and analysis. All data are presented as the mean \pm standard deviation of three independent experiments. FAK, focal adhesion kinase; SphK1, Sphingosine kinase 1; Con, control; NC, negative control. 
A

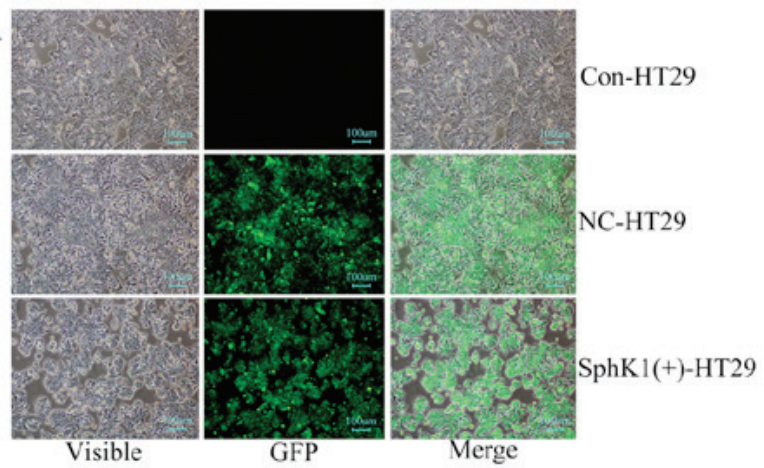

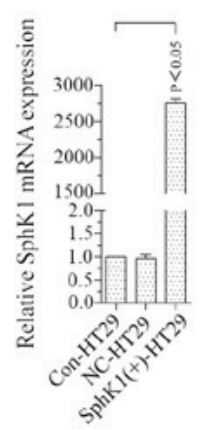

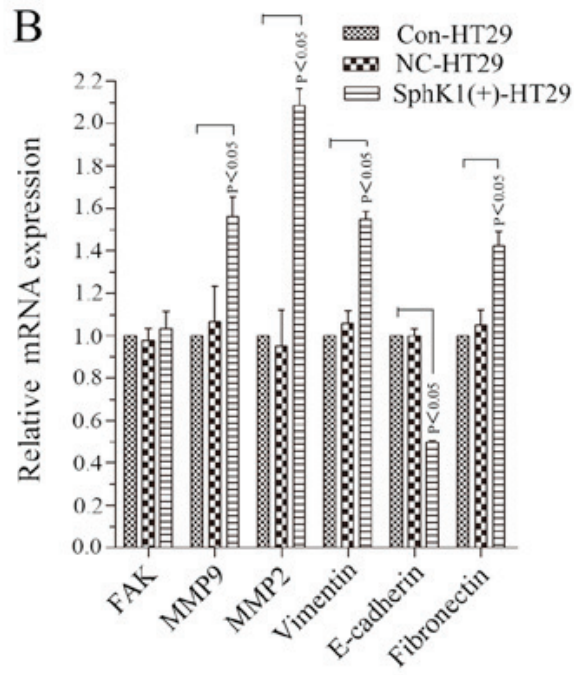

$\mathrm{C}$ HT29

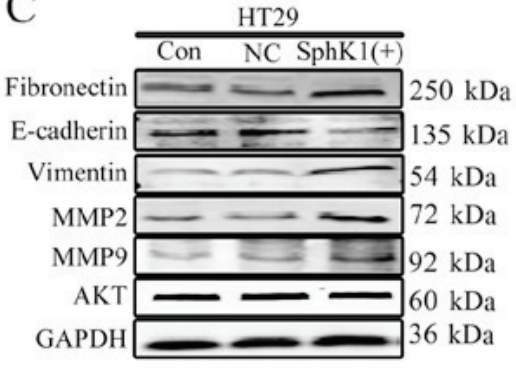

$\mathrm{D}$

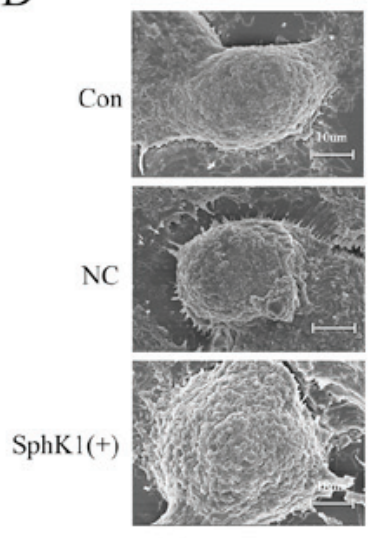

E

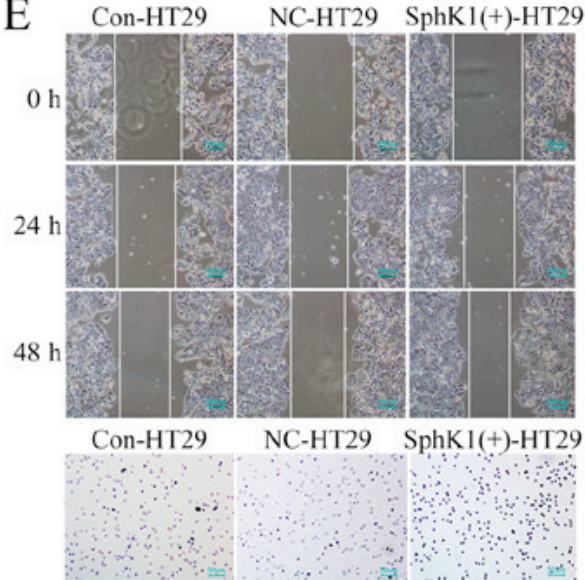

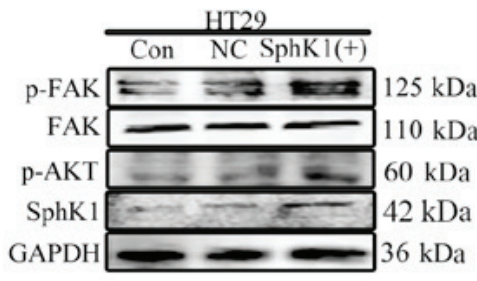

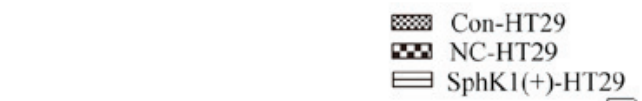

Figure 5. SphK1 overexpression strengthens cell migrational potency, epithelial-mesenchymal transition and the expression of p-FAK, p-AKT and MMPs in HT29 cells. (A) SphK1 expression in HT29 cells. Transfected and untransfected HT29 cells were detected by a fluorescence microscope (magnification, x100). RT-PCR analysis for SphK1 mRNA. (B) RT-PCR analysis of target molecules. GAPDH was used as a reference and the Con-HT29 was set to 1. (C) Western blot analysis. GAPDH was used as an internal control. (D) Microvilli and pseudopodia of Con, NC and SphK1(+)-HT29 cells under scanning electron microscopy (magnification, x 5.00k). (E) Cell migrational potency demonstrated by a wound healing assay (magnification, x100) and analysis. Cell migrational potency demonstrated by a Transwell assay (magnification, $\mathrm{x} 200$ ) and analysis. All data are presented as the mean \pm standard deviation of three independent experiments. SphK1, Sphingosine kinase 1; p, phosphorylated; FAK, focal adhesion kinase; AKT, protein kinase B; MMP, matrix metalloproteinase; RT-PCR, reverse transcription-polymerase chain reaction; Con, control; NC, negative control; GFP, green fluorescent protein.

Cell migrational potency, EMT, and the expression of p-FAK, $p$-AKT and MMPs are suppressed by FAK inhibitor in SphK1-overexpressing HT29 cells. As demonstrated in Fig. 6A, PF562271 (inhibitor of the FAK pathway) suppressed the proliferation of HT29 cells in a time- and dose- dependent manner. The protein expression of FAK was decreased when HT29 cells were treated with PF562271 at concentrations of 2.5 and $5 \mu \mathrm{M}$ for $48 \mathrm{~h}$. The protein expression of p-FAK was 

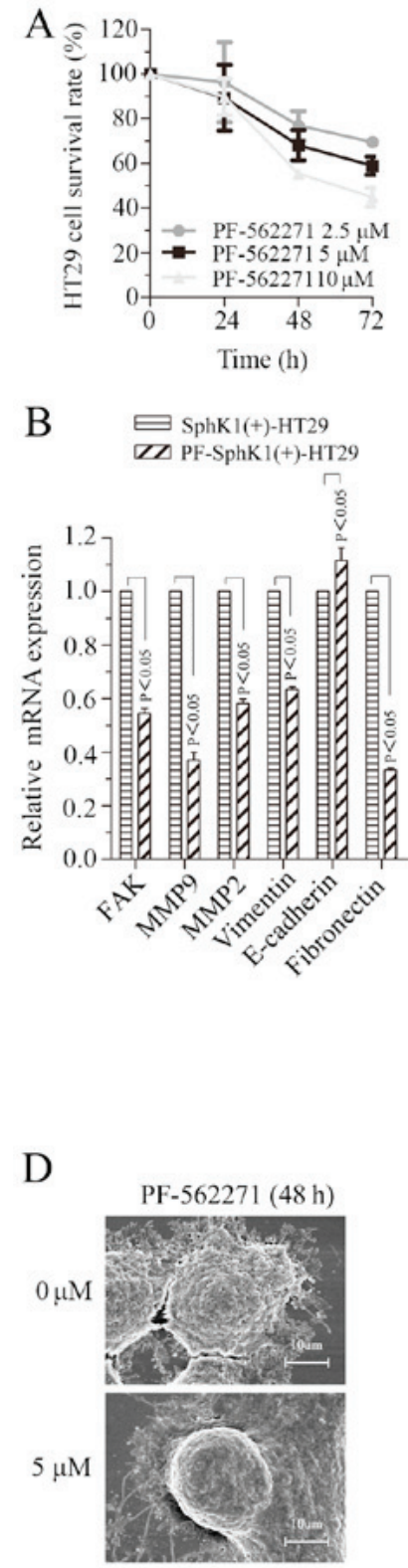

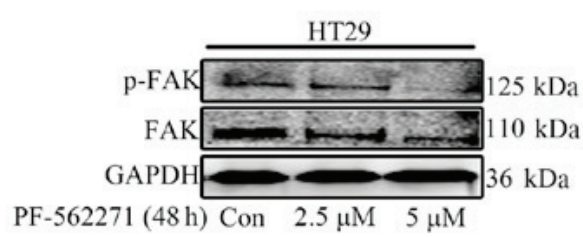

C
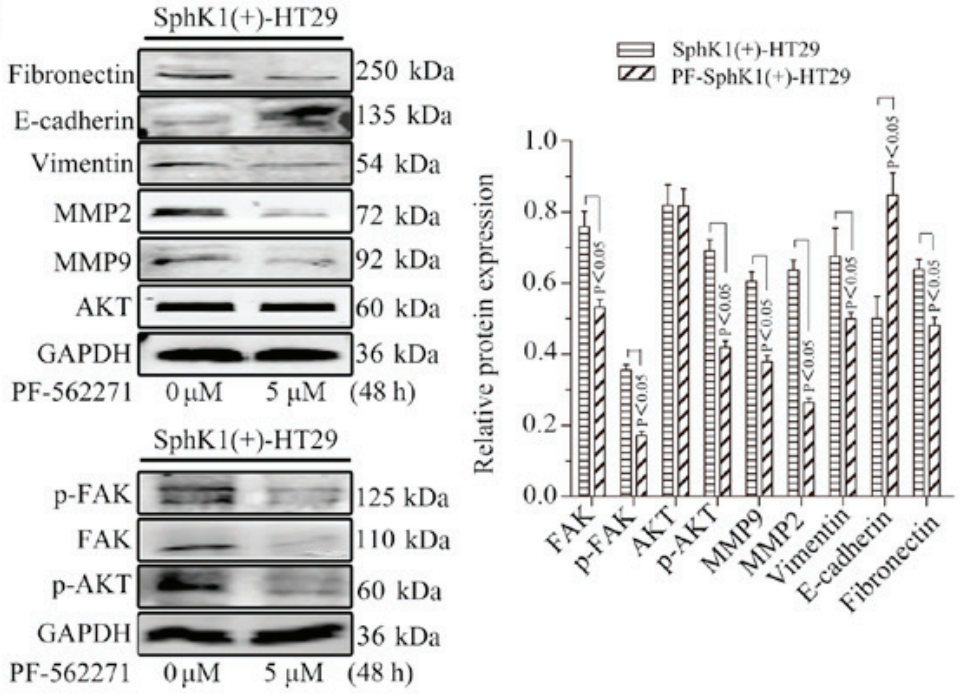

E SphK1(+)-HT29 PF-SphK1(+)-HT29
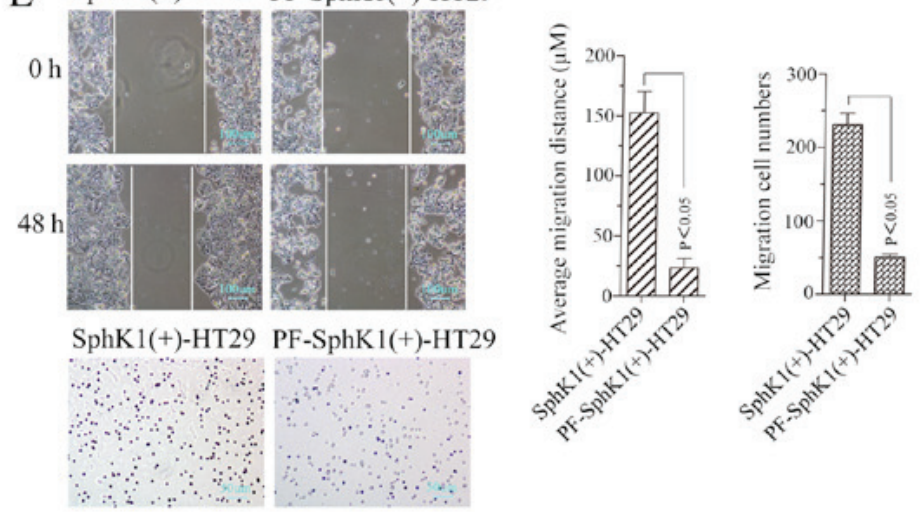

Figure 6. Cell migrational potency, epithelial-mesenchymal transition, and the expression of p-FAK, p-AKT and MMPs is suppressed by a FAK inhibitor in SphK1-overexpressing HT29 cells. (A) Survival rates of HT29 cells and western blot analysis. GAPDH was used as an internal control. (B) Reverse transcription-polymerase chain reaction analysis of target molecules. GAPDH was used as a reference and the SphK1(+)-HT29 was set to 1. (C) Western blot analysis. GAPDH was used as an internal control. (D) Microvilli and pseudopodia of SphK1(+)-HT29 and PF-SphK1(+)-HT29 cells under scanning electron microscopy (magnification, x5.00k). (E) Cell migrational potency demonstrated by a wound healing assay (magnification, x100) and analysis. Cell migrational potency demonstrated by a Transwell assay (magnification, $\mathrm{x} 200$ ) and analysis. All data are presented as the mean \pm standard deviation of three independent experiments. p, phosphorylated; FAK, focal adhesion kinase; AKT, protein kinase B; MMP, matrix metalloproteinase; SphK1, Sphingosine kinase 1; Con, control; PF, PF-562271.

significantly decreased when HT29 cells were treated with PF562271 at a concentration of $5 \mu \mathrm{M}$ for $48 \mathrm{~h}(\mathrm{P}<0.05)$. The expression of FAK, p-FAK, p-AKT and MMP2/9 was decreased when SphK1(+)-HT29 cells were treated with PF562271 at a concentration of $5 \mu \mathrm{M}$ for $48 \mathrm{~h}$ [PF-SphK1(+)-HT29]. However, there was no noticeable alteration in the expression level of AKT (Fig. 6B and C). In addition, the expression of E-cadherin was increased, whereas, vimentin and fibronectin expression levels were decreased in SphK1(+)-HT29 cells treated with PF562271 (Fig. 6B and C). Furthermore, the microvilli, pseudopodia and migrational potency of PF-SphK1(+)-HT29 cells were suppressed by treatment with PF562271 (Fig. 6D and E). These results suggested that the FAK pathway inhibitor suppressed the EMT and migrational potency induced by SphK1 overexpression in HT29 cells.

\section{Discussion}

SphK1 was identified to be overexpressed in various types of cancer cells and contributed to the development, progression, 
metastasis and chemo-resistance of cancer (2-6). Advanced invasion and metastasis are the key factors affecting cancer prognosis, and the leading causes of mortality in patients with cancer (27). The present study not only confirmed that the expression of SphK1 was increased in colorectal cancer cells; however, additionally demonstrated that it contributes to the metastasis and shorter survival time of patients with colorectal cancer. However, the molecular mechanism of SphK1 promoting the migration and metastasis of colon cancer cells requires further study.

EMT is considered a process of basic transformation during embryonic development. During EMT, epithelial cells may further boost polarity and transform into mesenchymal type cells capable of advanced migration under specific physiological and pathological conditions (28). In a previous study, the cancer cell migrational potency and the morphological transformation of cells microvilli and pseudopodia were enhanced when cells underwent EMT-associated alterations (29). In the present study, it was confirmed that the expression of E-cadherin decreased and vimentin increased in metastatic colorectal cancer tissues and SphK1-overexpressed colon cancer cells. The migrational potency was enhanced with the overexpression of SphK1, along with the microvilli and pseudopodia. E-cadherin is an adherens junction protein that forms homophilic intercellular contacts in epithelial cells; its downregulation is commonly observed in EMT cancer cells (30). Fibronectin serves an important role in the regulation of epithelial cell adhesion, allowing transition of cell-cell contacts to cell-extracellular matrix interactions during EMT (31). Vimentin contributes to EMT cancer cell mechanics by mediating cytoskeletal organization and focal adhesion maturation (32). It additionally promotes the cell intermediate filament status, altering from a keratin-rich network to a vimentin-rich network connecting to focal adhesions (32). Therefore, SphK1 contributed to the metastasis of colon cancer by inducing EMT.

FAK is a non-receptor tyrosine kinase that mediates integrin signaling from the sites of connection to the extracellular membrane termed focal adhesions. FAK mediates essential cellular processes, including growth, proliferation, adhesion, migration and survival through its functions as a molecular scaffold and as a kinase (33). It was observed that FAK promoted malignancy by regulating tumorigenic and migrational potency (34). Inhibition of FAK caused less mesenchymal-like characteristics and decreased the mobility and migrational potency of Hep2 cells and mesenchymal triple negative breast cancer cells (16). The results of the present study suggested that blocking FAK/p-FAK (Tyr397) suppressed the expression of fibronectin and vimentin, and enhanced E-cadherin in colon cancer cells. Cell migrational potency was inhibited by FAK knockdown. Furthermore, it was demonstrated in the present study and in our previous study that SphK1 promoted the migrational potency of colon cancer by regulating the FAK pathway (4). Induced by SphK1 overexpression, the EMT and migrational potency were suppressed by inhibition of the FAK pathway. These results demonstrated that SphK1 promoted the migrational potency of colon cancer by inducing EMT, which was mediated by FAK/p-FAK (Tyr397).

A previous study identified that SphK1 enhanced the migrational potency of non-small cell lung cancer cells by activating the AKT pathway (35). The expression of p-AKT in colon cancer cells was enhanced with the upregulation of SphK1 and suppressed with its downregulation. Notably, the expression of AKT/p-AKT, induced by the upregulation of SphK1 may be suppressed by the inhibitor of the FAK pathway. The PI3K/AKT pathway was involved in the regulation of cell mobility via activation of FAK, and associated phosphorylation of p 85 subunits of tyrosine of PI3K in human cancer cells (22). PI3K, an upstream activator of AKT (36), activated AKT by promoting the phosphorylation of the serine phosphorylation site (Ser473) of AKT (37). AKT was frequently dysregulated in tumors and served a pivotal role in tumor metastasis (38). Therefore, SphK1 promoted the migration and metastasis of colorectal cancer by inducing EMT, which was mediated by the FAK/AKT pathway.

It has been suggested that SphK1 expression promoted the secretion of MMP-2/9 and urokinase-type plasminogen activator (39). The indicated molecular mechanisms are important for the regulation of malignant behavior, including invasiveness, in colon cancer (39). The expression of MMP-2/9 was suppressed with the downregulation of SphK1, p-FAK and $\mathrm{p}-\mathrm{AKT}$. The PI3K/AKT/nuclear factor (NF)- $\mathrm{KB}$ pathway was involved in the upregulation of MMPs (39). AKT regulates MMP2/9 gene expression by promoting p65- and p52-DNA-binding activities of NF- $\mathrm{BB}$ (40). Furthermore, MMP2/9 are crucial for the remodeling of the extracellular matrix (41). These results suggested that SphK1 promoted the migration and metastasis of colorectal cancer by inducing EMT, which was mediated by the FAK/AKT/MMPs axis.

In summary, SphK1 promoted the metastasis of colorectal cancer through induction of the EMT, which was mediated by the FAK/AKT/MMPs axis. The association of SphK1 with EMT requires further examination as a potential therapeutic target in the treatment of colorectal cancer.

\section{Acknowledgements}

Not applicable.

\section{Funding}

The present study was supported by the National Natural Science Foundation of China (grant nos. 81460380 and 81760516) and Innovation Project of Guangxi Graduate Education (grant no. YCBZ2017035).

\section{Availability of data and materials}

All data generated or analyzed during the current study are included in this published article.

\section{Authors' contributions}

CYX and SQL performed the studies and drafted the manuscript. WHW, ZHF and SWH collected the clinical data and tissue samples. CYX and MBQ performed the statistical analysis. SQL and JAH designed the study and helped draft the manuscript. All authors read and approved the final manuscript. 


\section{Ethics approval and consent to participate}

This present study was approved by the Ethics Committee of the First Affiliated Hospital of Guangxi Medical University (Guangxi, China). Written informed consent was obtained from all patients.

\section{Patient consent for publication}

Consent for the publication of the clinical and pathological data was obtained from all patients who were involved in the present study.

\section{Competing interests}

The authors declare that they have no competing interests.

\section{References}

1. Jie D, Zhongmin Z, Guoqing L, Sheng L, Yi Z, Jing W and Liang Z: Positive expression of LSD1 and negative expression of E-cadherin correlate with metastasis and poor prognosis of colon cancer. Dig Dis Sci 58: 1581-1589, 2013.

2. Li J, Wu H, Li W, Yin L, Guo S, Xu X, Ouyang Y, Zhao Z, Liu S, Tian Y, et al: Downregulated miR-506 expression facilitates pancreatic cancer progression and chemoresistance via SPHK1/Akt/NF- $\kappa$ B signaling. Oncogene 35: 5501-5514, 2016

3. Long J, Xie Y, Yin J, Lu W and Fang S: SphK1 promotes tumor cell migration and invasion in colorectal cancer. Tumour Biol 37 $6831-6836,2016$

4. Zheng XD, Zhang Y, Qi XW, Wang MH, Sun P, Zhang Y and Jiang J: Role of Sphk1 in the malignant transformation of breast epithelial cells and breast cancer progression. Indian J Cancer 51: 524-529, 2014

5. Su YJ, Huang JA, Liu SQ, Huang JX, Zhong YY, Tang GD and Jiang HX: The expression and clinical significance of SphK1 and nuclear factor- $\kappa \mathrm{B}$ p65 in human colon carcinoma. Zhonghua Nei Ke Za Zhi 51: 220-224, 2012

6. Liu SQ, Su YJ, Qin MB, Mao YB, Huang JA and Tang GD Sphingosine kinase 1 promotes tumor progression and confers malignancy phenotypes of colon cancer by regulating the focal adhesion kinase pathway and adhesion molecules. Int J Oncol 42: 617-626, 2013

7. Cai G, Wu D, Wang Z, Xu Z, Wong KB, Ng CF, Chan FL and Yu S: Collapsin response mediator protein-1 (CRMP1) acts as an invasion and metastasis suppressor of prostate cancer via its suppression of epithelial-mesenchymal transition and remodeling of actin cytoskeleton organization. Oncogene 36: 546-558, 2017.

8. Leonel C, Borin TF, de Carvalho Ferreira L, Moschetta MG Bajgelman MC, Viloria-Petit AM and de Campos Zuccari DA: Inhibition of epithelial-mesenchymal transition and metastasis by combined TGFbeta knockdown and metformin treatment in a canine mammary cancer xenograft model. J Mammary Gland Biol Neoplasia 22: 27-41, 2017.

9. Singla M, Kumar A, Bal A, Sarkar S and Bhattacharyya S: Epithelial to mesenchymal transition induces stem cell like phenotype in renal cell carcinoma cells. Cancer Cell Int 18: 57, 2018.

10. Liu CC, Cai DL, Sun F, Wu ZH, Yue B, Zhao SL, Wu XS, Zhang M, Zhu XW, Peng ZH, et al: FERMT1 mediates epithelial-mesenchymal transition to promote colon cancer metastasis via modulation of $\beta$-catenin transcriptional activity. Oncogene 36: 1779-1792, 2017.

11. Harner-Foreman N, Vadakekolathu J, Laversin SA, Mathieu MG Reeder S, Pockley AG, Rees RC and Boocock DJ: A novel spontaneous model of epithelial-mesenchymal transition (EMT) using a primary prostate cancer derived cell line demonstrating distinct stem-like characteristics. Sci Rep 7: 40633, 2017

12. Chiu LY, Hsin IL, Yang TY, Sung WW, Chi JY, Chang JT, Ko JL and Sheu GT: The ERK-ZEB1 pathway mediates epithelial-mesenchymal transition in pemetrexed resistant lung cancer cells with suppression by vinca alkaloids. Oncogene 36: 242-253, 2017
13. Yang Y, Zhang J, Yan Y, Cai H, Li M, Sun K, Wang J, Liu X, Wang $J$ and Duan X: Low expression of Rap1GAP is associated with epithelial-mesenchymal transition (EMT) and poor prognosis in gastric cancer. Oncotarget 8: 8057-8068, 2017.

14. Lv QL, Chen SH, Zhang X, Sun B, Hu L, Qu Q, Huang YT, Wang GH, Liu YL, Zhang YY, et al: Upregulation of long noncoding RNA zinc finger antisense 1 enhances epithelial-mesenchymal transition in vitro and predicts poor prognosis in glioma. Tumour Biol 39: 1010428317695022, 2017.

15. Ling HH, Kuo CC, Lin BX, Huang YH and Lin CW: Elevation of YAP promotes the epithelial-mesenchymal transition and tumor aggressiveness in colorectal cancer. Exp Cell Res 350: 218-225, 2017.

16. Taliaferro-Smith L, Oberlick E, Liu T, McGlothen T, Alcaide T, Tobin R, Donnelly S, Commander R, Kline E, Nagaraju GP, et al: FAK activation is required for IGF1R-mediated regulation of EMT, migration, and invasion in mesenchymal triple negative breast cancer cells. Oncotarget 6: 4757-4772, 2015.

17. Huang L, Huang Z, Fan Y,He L, Ye M, Shi K, Ji B, Huang J, Wang Y and Li Q: FOXC1 promotes proliferation and epithelial-mesenchymal transition in cervical carcinoma through the PI3K-AKT signal pathway. Am J Transl Res 9: 1297-1306, 2017.

18. Xu H, Li M, Zhou Y, Wang F, Li X, Wang L and Fan Q: S100A4 participates in epithelial-mesenchymal transition in breast cancer via targeting MMP2. Tumour Biol 37: 2925-2932, 2016.

19. Asuthkar S, Nalla AK, Gondi CS, Dinh DH, Gujrati M, Mohanam S and Rao JS: Gadd45a sensitizes medulloblastoma cells to irradiation and suppresses MMP-9-mediated EMT. Neuro-oncol 13: 1059-1073, 2011.

20. Baquero P, Jiménez-Mora E, Santos A, Lasa M and Chiloeches A: TGF $\beta$ induces epithelial-mesenchymal transition of thyroid cancer cells by both the BRAF/MEK/ERK and Src/FAK pathways. Mol Carcinog 55: 1639-1654, 2016.

21. Yang J, Hou Y, Zhou M, Wen S, Zhou J, Xu L, Tang X, Du YE, $\mathrm{Hu} \mathrm{P}$ and Liu M: Twist induces epithelial-mesenchymal transition and cell motility in breast cancer via ITGB1-FAK/ILK signaling axis and its associated downstream network. Int J Biochem Cell Biol 71: 62-71, 2016

22. Xue X, Wang X, Liu Y, Teng G, Wang Y, Zang X, Wang K, Zhang J, Xu Y, Wang J, et al: SchA-p85-FAK complex dictates isoform-specific activation of Akt2 and subsequentPCBP1-mediated post-transcriptional regulation of TGF $\beta$-mediated epithelial to mesenchymal transition in human lung cancer cell line A549. Tumour Biol 35: 7853-7859, 2014.

23. Lv C, Yang S, Chen X, Zhu X, Lin W Wang L, Huang Z, Wang M and Tu G:: MicroRNA-21 promotes bone mesenchymal stem cells migration in vitro by activating PI3K/Akt/MMPs pathway. J Clin Neurosci 46: 156-162, 2017.

24. Qin M, Liu S, Li A, Xu C, Tan L, Huang J and Liu S: NIK- and IKK $\beta$-binding protein promotes colon cancer metastasis by activating the classical NF- $\mathrm{B}$ pathway and MMPs. Tumour Biol 37: 5979-5990, 2016

25. Livak KJ and Schmittgen TD: Analysis of relative gene expression data using real-time quantitative PCR and the 2(-Delta Delta C(T)) Method. Methods 25: 402-408, 2001.

26. Xu CY, Liu SQ, Qin MB, Zhuge CF, Qin L, Qin N, Lai MY and Huang JA: SphK1 modulates cell migration and EMT-related marker expression by regulating the expression of p-FAK in colorectal cancer cells. Int J Mol Med 39: 1277-1284, 2017.

27. Li S, Zhou Y, Zheng X, Wu X, Liang Y, Wang S and Zhang Y: Sphk1 promotes breast epithelial cell proliferation via NF- $\mathrm{B}-\mathrm{p} 65$-mediated cyclin D1 expression. Oncotarget 7: 80579-80585, 2016.

28. Yeung KT and Yang J: Epithelial-mesenchymal transition in tumor metastasis. Mol Oncol 11: 28-39, 2017.

29. Gu K, Li MM, Shen J, Liu F, Cao JY, Jin S and Yu Y: Interleukin-17-induced EMT promotes lung cancer cell migration and invasion via NF- $\mathrm{BB} / \mathrm{ZEB} 1$ signal pathway. Am J Cancer Res 5: 1169-1179, 2015.

30. Dai S, Zhang J, Huang S, Lou B, Fang B, Ye T, Huang X, Chen B and Zhou M: HNRNPA2B1 regulates the epithelial-mesenchymal transition in pancreatic cancer cells through the ERK/snail signalling pathway. Cancer Cell Int 17: 12, 2017.

31. Park J and Schwarzbauer JE: Mammary epithelial cell interactions with fibronectin stimulate epithelial-mesenchymal transition. Oncogene 33: 1649-1657, 2014.

32. Kokkinos MI, Wafai R, Wong MK, Newgreen DF, Thompson EW and Waltham M: Vimentin and epithelial-mesenchymal transition in human breast cancer--observations in vitro and in vivo. Cells Tissues Organs 185: 191-203, 2007. 
33. Kessler BE, Sharma V, Zhou Q, Jing X, Pike LA, Kerege AA, Sams SB and Schweppe RE: FAK expression, not kinase activity, is a key mediator of thyroid tumorigenesis and protumorigenic processes. Mol Cancer Res 14: 869-882, 2016.

34. Lee BY, Timpson P, Horvath LG and Daly RJ: FAK signaling in human cancer as a target for therapeutics. Pharmacol Ther 146: 132-149, 2015.

35. Zhu L, Wang Z, Lin Y, Chen Z, Liu H, Chen Y, Wang N and Song $X$ : Sphingosine kinase 1 enhances the invasion and migration of non-small cell lung cancer cells via the AKT pathway. Oncol Rep 33: 1257-1263, 2015.

36. Bugide S, Gonugunta VK, Penugurti V, Malisetty VL, VadlamudiRK and Manavathi B: HPIP promotes epithelial-mesenchymal transition and cisplatin resistance in ovarian cancer cells through PI3K/AKT pathway activation. Cell Oncol (Dordr) 40: 133-144, 2017.

37. Fu QF, Liu Y, Fan Y, Hua SN, Qu HY, Dong SW, Li RL, Zhao MY, Zhen Y, Yu XL, et al: Alpha-enolase promotes cell glycolysis, growth, migration, and invasion in non-small cell lung cancer through FAK-mediated PI3K/AKT pathway. J Hematol Oncol 8: 22, 2015.

38. Yang Y, Qiu S, Qian L, Tian Y, Chen Y, Bi L and Chen W: OCF can repress tumor metastasis by inhibiting epithelial-mesenchymal transition involved in PTEN/PI3K/AKT pathway in lung cancer cells. PLoS One 12: e0174021, 2017.
39. Liu SQ, Huang JA, Qin MB, Su YJ, Lai MY, Jiang HX and Tang GD: Sphingosine kinase 1 enhances colon cancer cell proliferation and invasion by upregulating the production of MMP-2/9 and uPA via MAPK pathways. Int J Colorectal Dis 27: 1569-1578, 2012.

40. Su Y, Gao L, Teng L, Wang Y, Cui J, Peng S and Fu S: Id1 enhances human ovarian cancer endothelial progenitor cell angiogenesis via PI3K/Akt and NF-кB/MMP-2 signaling pathways. J Transl Med 11: 132, 2013

41. Yuan H, Yang P, Zhou D, Gao W, Qiu Z, Fang F, Ding S and Xiao W: Knockdown of sphingosine kinase 1 inhibits the migration and invasion of human rheumatoid arthritis fibroblast-like synoviocytes by down-regulating the PI3K/AKT activation and MMP-2/9 production in vitro. Mol Biol Rep 41: $5157-5165,2014$

This work is licensed under a Creative Commons Attribution-NonCommercial-NoDerivatives 4.0 International (CC BY-NC-ND 4.0) License. 